\title{
Svekket personvern med e-resept
}

\author{
Elektroniske resepter har mange fordeler, men personvernet må ikke bli svekket. Løsningen som er valgt \\ for e-resepter har mange svakheter sammenliknet med papirreseptene.
}

Allerede i 1970-årene, da det ble utviklet ITsystemer for helsesektoren, var det aktuelt å tilby elektroniske resepter. Fordelene var åpenbare: Større sikkerhet for at pasienten fikk den medisinen legen forordnet, bedre oversikt og bedre kontroll. Imidlertid fant man ut at vi nok måtte beholde papiret $i$ enda noen år. Dette var 35 år siden! Først i dag er man i ferd med å innføre en elektronisk løsning - en e-resept.

Som kjent sendes en e-resept elektronisk fra legen til en sentral database som apotekene har tilgang til. Pasienten kan velge apotek fritt. Man må oppgi personnummer (eller navn og fødselsdato), og ut fra dette vil apoteket finne frem til resepten. Der apoteket tidligere kun fikk se den papirresepten pasienten kom med, vil de nå få oversikt over alle pågående resepter.

I praksis vil denne listen være et meget godt sammendrag av journalen - i hvert fall for de problemer og sykdommer pasienten har $i$ dag. Vet man hvilken medisiner som gis, vet man også mye om hvilke sykdommer pasienten har.

Nå har apotekansatte, akkurat som legene, taushetsplikt. For å kunne holde opplysninger konfidensielle er det likevel viktig at færrest mulig kjenner til dem.

$\AA ̊$ gjøre medisinske opplysninger potensielt tilgjengelig for over 7000 apotekansatte er ingen god idé.

Elektroniske løsninger har mange fordeler, men de bør ikke føre til svekket personvern. Med den løsningen som er valgt, er det flere svakheter sammenliknet med resepter på papir. Det er i prinsippet mulig for en apotekansatt å finne ut hvilke medisiner ektefellen, kjæresten eller en annen person tar. Visstnok kreves det en avviksmelding når et apotek ikke effektuerer et

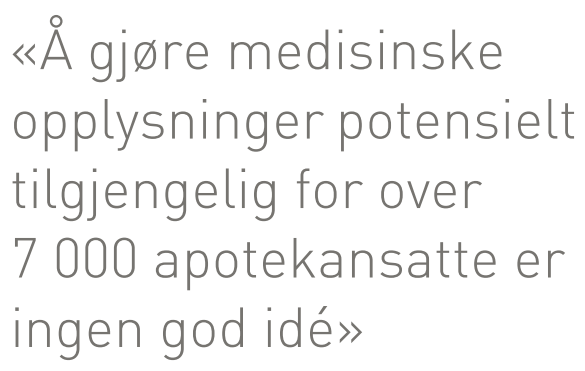

salg av et legemiddel etter å ha åpnet reseptene på et personnummer, men fordi det vil være mange grunner til slike avvik, kan dette bli noen man kan gjøre av og til uten at det virker mistenkelig.

En vanlig person kan også få vite mye bare ved å oppgi en annens personnummer på apoteket. Selvsagt får man ikke se skjermen, men den apotekansatte vil gjerne spørre om hvilken medisin vedkommende skal ha. Da kan man bortforklare det hele med at det var en glipp, men i verste fall kan man få med seg preparater ment for andre.

Pasienten kan be legen om at en resept låses. Da vil man få et referansenummer som må oppgis på apoteket. Disse reseptene vil ikke vises under personnummeret. Det vil da være samme sikkerhet som i det gamle systemet med papirresepter. Med e-reseptsystemet er dette presentert som en unntaksmulighet. Ifølge mitt apotek hadde de ennå ikke fått noen slik låst resept, men det kan skyldes at ikke så mange har tatt i bruk e-reseptordningen.

Men hvorfor ikke la alle resepter være låst? Med resepter som visuelle koder, som strekkode eller som de nyere QR-kodene, på papir eller per mobiltelefon kan reseptkoden leses automatisk på apoteket. Det er enklere enn å bruke personnummer - og langt sikrere. Det ville løse alle de sikkerhetsproblemer man har med dagens ordning for elektroniske resepter.

\section{Kai A. Olsen}

kai.a.olsen@himolde.no

Kai A. Olsen (f. 1950) er professor i informatikk ved Høgskolen i Molde og ved Universitetet i Bergen.

Forfatter har fylt ut ICMJE-skjemaet og oppgir ingen interessekonflikter.

Mottatt 4.10.2012 og godkjent 18.10. 2012. Medisinsk redaktør Petter Gjersvik.

Publisert først på nett 2.11. 2012 